\title{
Application of the Instrumentarium of a Visual-Narrative Approach in Psychological Assistance to Personality
}

\section{Застосування інструментарію візуально-наративного підходу у психологічній допомозі особистості}

\author{
Vitaliia Shebanova \\ Dr. in Psychology, \\ Professor
}

\section{Віталія Шебанова}

доктор психологічних наук, професор

E-mail: vitaliashebanova@gmail.com
orcid.org/0000-0002-1658-4691

Nataliia Tavrovetska

Ph.D. in Psychology, Associate Professor, Head of the Department of Practical Psychology

\section{Наталія Тавровецька} кандидат психологічних наук, доцент, завідувач кафедри практичної психології

E-mail: 1882181@gmail.com orcid.org/0000-0002-9497-7386

Kherson

State University

27, University Str., Kherson, Ukraine, 73000
Херсонський державний університет $\triangle$ вул. Університетська, 27, м. Херсон, Україна, 73000

Original manuscript received April 21, 2018 Revised manuscript accepted October 19, 2018

\section{ABSTRACT}

The article focuses on the application of a visual-narrative approach in providing psychological assistance to personality. It is shown that the narrative approach is now widely used by specialists, in solving a wide range of 
psychological problems of personality, in normalization of a psychological state of personality in crisis and traumatic situations.

The implementation of the narrative approach is done through the creation of oral and written texts while providing psychological assistance. The combination of a verbal creative product with metaphorical associative maps, photographs, leaflets, illustrations, mandalas, etc., allows us to distinguish the visual and narrative approach. "Texts» as a response to visual stimuli (associative maps, photographs, illustration, mandalas, etc.) can be of any character (biographical or imaginative) and any style (prose, rhymed and unrhymed verses, tales, personal stories, essays, etc.). In one version, the visual series may be primary, and the texts are secondary. In this case, "text" can be simply a detailed comment of the group member (client) or a creative author's text, which is made by the client. In another version, on the contrary, the texts can be primary, and then they receive visual stimuli, which are also further described and analyzed in their connection with the real life story of the client. The main points and principles of the narrative approach are presented. The stages of narrative psychotherapy are given: externalization of the problem (distancing the "problem" from a person); design (reconstruction) - a critical analysis of ideas that were uncritically learned that is, a kind of "unpacking» or "contextualization". It is shown that the narrative approach is considered as: - a means of the development of personality traits, the achievement of identity; - a form of awareness of personal experience; - a means of organizing a personal future and selfconstitution; the method of intergenerational history analysis or correctional family psychotherapeutic method. The emphasis is placed on the special value of this approach as an effective means of psychological self-help.

Key words: visual-narrative approach, psychological help, self-help, crisis situations, traumatic situations, search of resources, self-and life-design.

«Ніхто не має бути жертвою власної біографії» Джордж Келлі

\section{Вступ}

Впродовж тривалого часу (з 2013 р. і до нині) доросле та дитяче насилля України знаходиться у травматичній ситуації в ситуації військової агресії. Суспільство переживає такі події, що порушують базове почуття безпеки, являють собою загрозу здоров'ю та життю, викликають почуття безпорадності, жаху та руйнують звичайний плин життя та життєконструювання. Беззаперечно, що осторонь не залишається ніхто - ні ті, хто ризикує 
Application of the Instrumentarium of a Visual-Narrative Approach...

життям на полі бою; ні ті, хто чекає своїх відважних та шляхетних захисників вдома; ні ті, хто вимушені покинути власні домівки та шукати інше житло, місце роботи, навчання...; ні ті, хто слідкує за новинами;... і навіть ті, хто, як би відсторонюються від всього, що відбувається - все рівно залучені у суспільно-політичні процеси i трансформації, що відбуваються нині в Україні. Саме тому необхідність психологічної допомоги дорослим, дітям, родинам набуває практично загально масштабу. Це і потребує застосування таких інструментів психологічної допомоги особистості, що перебуває у складних життєвих обставинах (та/або знаходиться в умовах хронічного стресу та/або має посттравматичні стресові розлади), які б дозволяли ефективно та у максимально швидкі терміни здійснити діагностику та корекцію іiі психічних станів, смислів, ціннісних орієнтацій, поведінки, стосунків з оточуючими; допомогли б знайти вихід з кризової ситуації; розкрили б ресурси життєздійснення особистості у період їі трансформацій.

Аналіз досліджень проведених у галузі психолінгвістики, психотерапії, психологічного консультування та досвіду роботи практичних психологів дозволяє стверджувати, що на сьогодні наративний підхід розглядається як засіб розвитку особистісних особливостей, досягнення ідентичності (Жорняк, 2005; Сарбін, 2004; Berntsen, 2011 та ін.), форма усвідомлення особистого досвіду (Bruner, 2003; White, 2007; Чепелєва, 2010; Pesco \& Kay-Raining Bird, 2016; Busquets, 2018 та ін.), засіб організації особистісного майбутнього і самоконституювання (Титаренко, 2010; Чабан, 2012 та ін.), метод аналізу міжпоколінноїісторії (Чаусова, 2011; Nicnols \& Schwartz, 2012 та ін.) або корекційний сімейний психотерапевтичний метод (Калмиков, 2017; Копитін \& Корт, 2011; Goldenberg \& Goldenberg, 2012 та ін.). Однак, незважаючи на вищеописані аспекти застосування наративного підходу у психологічну практику, деякі аспекти, зокрема застосування інструментарію візуально-наративного підходу при наданні психологічної допомоги до цього часу залишаються недостатньо презентованими.

Мета статті - обгрунтувати та продемонструвати можливості візуально-наративного підходу при наданні психологічної допомоги особистості у різних життєвих і травматичних ситуаціях. 


\section{Методи дослідження}

Нами використано комплекс теоретичних методів (логікопсихологічний аналіз, систематизація і наукова інтерпретація), а також емпіричні методи (дискурс-аналіз, інтент-аналіз, контентаналіз) задля обгрунтування застосування інструментарію візуально-наративного підходу щодо надання психологічної допомоги особистості.

\section{Результати дослідження}

На сьогодні наративний підхід $є$ одним 3 підходів, що широко застосовуються фахівцями при наданні психологічної допомоги, щодо розв'язання різного спектру психологічних проблем особистості, нормалізації психологічного стану особистості у кризових і травматичних ситуаціях.

Зауважимо, що застосування наративного підходу при наданні психологічної допомоги пов'язано 3 так званим «наратологічним поворотом», тобто широкою експансією наратології в інші дисципліни - психологію, соціологію, теологію, історію, право і триває від 90-х років минулого століття до нашого часу.

Реалізація наративного підходу здійснюється завдяки створенню усних та письмових текстів під час психокорекційної терапії. Поєднання вербального творчого продукту з метафоричними асоціативними картами, фотографіями, листівками, малюнками, мандалами тощо дозволяє виокремлювати візуально-наративний підхід*. «Тексти» як відгук на візуальні стимули (асоціативні карти, фотографіі, малюнок, мандалу та ін.) можуть бути будь-якого характеру (біографічного або фантазійного) та будь-якого стилю (проза, римовані та неримовані вірші, казки, особисті iсторії, есе та ін.). В одному варіанті візуальний ряд може бути первинними, а тексти вторинними. При цьому «текстом» може бути просто розгорнутий коментар учасника групи (клієнта) або творчий авторський текст, який складає клієнт. В іншому варіанті, навпаки, первинними можуть бути тексти, а до них потім добираються візуальні стимули, які теж у подальшому описуються та аналізуються в їхньому зв'язку з реальним життям (реальною життєвою історією) клієнта.

* Термін М.-Л. Раян, що передбачає створення ментального образу оповідної реальності. 
Application of the Instrumentarium of a Visual-Narrative Approach...

Методологічну та теоретичну основу підходу складають ідеї культурно-історичної теорії Л.С. Виготського (1999), наративної психологіï (Брунер, 2003; Сарбін, 2004 та ін.), французької філософії постструктуралізму (Делез, 1993; Дерріда, 1973; Фуко, 1980 та ін.), антропології переживання (Гірц, 1973; Майерхофф, 1992; Тернер, 2001 та ін.), драматургічної соціології (Гоффман, 1986 та ін.). На думку П. Рея та С. Андерсона, більш правильним було б вважати наративну практику культурнокреативним підходом (Рей \& Андерсон, 2001).

Засновниками наративної терапії $є$ М. Уайт та Д. Епстон, які у своїй книзі, що була присвячена питанням терапії на основі наративного підходу, обгрунтували основні положення, принципи i поняття (Уайт \& Епстон, 1990).

Наративний підхід належить до нон-структуралістських. Прихильники наративного підходу поділяють уявлення про те, що будь-яке знання - це знання 3 певної позиції, тобто знання контекстуалізоване. Жодне описання світу не може претендувати на універсальність, тому насправді можлива необмежена безліч описів світу. Відповідно, до опису світу не можуть застосовуватися критерії «істинності» або «хибності», а тільки критерії правдоподібності, узгодженості (поряд 3 естетичними та прагматичними критеріями). Описи також відрізняються за тим, відкривають або закривають вони людині можливості для реалізації їі цінностей, мрій, надій тощо. Коли в житті людини домінує історія, яка закриває можливості, ми можемо говорити про існування проблеми. Однак у житті людини завжди со-існує безліч історій і крім проблемної історії (тієё, яка домінує), є щзе альтернативні (бажані) історії. Жодна проблема не захоплює життя людини на 100\%. Інакше кажучи, крім «проблеми» в житті людини завжди присутні інші області (сфери, зони, моменти життя), які цією проблемою не є. Завжди є якісь ресурси та якийсь досвід, на основі яких можливо реалізувати наміри i досягти поставлених цілей (які, однак, поки не включені в життєву історію людини).

Це означає, що поведінка людини не вважається маніфестацією тих чи інших структурних характеристик ऑii особистості або будь-яких структурних особливостей тих взаємин, до яких людина включена. Наративні психотерапевти причини вчинків шукають саме в сфері смислів, а не в сфері тих чи інших порушених «потреб», 
«дисфункцій», «особистісних розладів» тощо. Тому у наративному підході говорять про вчинки, які здійснюються у певних умовах відповідно до цінностей та намірів людини або всупереч ним, а не про якісь «глибинні» якості, властивості та порушення, які здатний осягнути тільки проникливий експерт-психолог або психіатр (і відповідно, сама людина, без фахівця, збагнути не може).

Сучасне уявлення про наратив у гуманітарних науках містить два його розуміння: наратив у широкому сенсі - це сюжетно та хронологічно організоване усне або письмове оповідання, у вузькому смислі - певний спосіб організації особистісного досвіду. Н.В. Чепелєва визначає наратив як «замкнену завершену структуру, що включає такі характеристики, як послідовність і завершеність дій, події, що змінюють одна одну і розміщені у хронологічному або ж іншому, підпорядкованому якійсь єдиній логіці, порядку, оцінки найбільш значущих подій, афективне ставлення до них оповідача (Чепелєва, 2010: 14). При цьому виокремлюється центральна тема або декілька тем, які є головними у наративі і на яких наголошує автор. Окрім розповідача, або наратора, існує слухач, який не просто сприймає сюжет наративу, а $і$ є його активним співавтором, тобто процес створення наративу є діалогічним (Чепелєва, 2010: 18).

Серед принципів наративної терапії автори виокремлюють насамперед: взаємну повагу, рівність позицій терапевта і клієнта, підтримку, відкритість, довіру, співробітництво, щирий інтерес, позицію «не-знання», стимулювання прагнення «стати творцем своєї унікальної історії», фокусування уваги клієнта на позитивних моментах його життя (тобто на тих моментах життя, коли людина виявляла кращі, сильні сторони своєї особистості і демонструвала свої можливості).

Візуально-наративний підхід тісно пов'язаний 3 постмодерністським розумінням дискурсу як способу вербальної та візуальної комунікації з системою значень, яка йому відповідає i яка тісно пов'язана $з$ культурними і соціальними умовами життя людей. Значний внесок у наративну терапію здійснив М. Фуко, який розробив поняття дискурсів (Фуко, 1980). Автор розглядав дискурс як певний світогляд - систему тверджень, практик, встановлених структур, які є спільними цінностями. Дискурси - це інтерналізовані наративи культури, знання, які сприймаються як істина (хоча 
Application of the Instrumentarium of a Visual-Narrative Approach...

насправді вони умовні i $€$ всього лише загальновизнаною домовленістю). Дискурси є в будь-якій сфері відносин.

У практичній роботі психолога як ведучого групи (або під час індивідуальної психокорекційної терапії) застосування візуальнонаративного підходу передбачає організацію сприятливих умов щодо створення творчого вербального продукту учасниками групи (клієнтом) своєї «особистої історії». Створення таких історій на основі візуально-наративного підходу дозволяє людині досліджувати значення вербальних i/або візуальних образів, встановити між ними логічні зв'язки, організувати та осмислити свій досвід, відчути спадкоємність досвіду, висловити своє світосприйняття, усвідомити свою ідентичність і зв'язок особистої історії 3 соціокультурним контекстом. Чимале значення у межах візуально-наративного підходу має рефреймінг, який дозволяє змінити значення образів залежно від контексту, що фактично означає «переписування» проблеми або особистої історії людини. Ю.А. Чаусова зазначає здатність наративу поєднувати минуле, теперішнє та майбутнє в єдину історію. При цьому, перетинаючись один 3 одним, вони можуть набувати різний зміст, трансформуючись зі зміною життєвих поглядів людини, іiі уявлень про минуле та теперішнє, планів на майбутнє. Індивідуальна розповідь охоплює весь простір життя особистості, адже людське минуле, теперішнє та майбутнє усвідомлюються і певним чином тлумачаться тільки в межах певного оповідання про себе, своє життя, свої плани (Чаусова, 2011: 229). На думку Т.М. Титаренко: «У нас немає іншого способу описання свого грядущого, свого прийдешнього, ніж продовження історії, розпочатої сьогодні чи вчора» (Титаренко, 2010: 5-6).

Наративні психотерапевти, Дж. Фрідман і Г. Комбс, відзначають: «наше сприйняття реальності організовується та підтримується за допомогою створення історій. Ми використовуємо їх для того, щоб оформити і передати інформацію про самих себе та інших людей. ... Для багатьох психотерапевтів, котрі керуються цим підходом, уявлення про приховану структуру психіки поступилося місцем уявленням про визначальну роль метафор мови, історій i їх значень» (Фрідман \& Кобс, 1996: 243). Поряд з цим, М. Ніколз i Р. Шварц відзначають, що у фокусі уваги психотерапевтів, які спираються на наративний підхід, є не стільки прагнення змінити поведінку, скільки зміна значень особистого досвіду клієнтів. 
На їх думку: «Наративні психотерапевти не вирішують проблем своїх клієнтів. Вони сприяють звільненню клієнтів від ілюзій, в які вони були занурені під впливом культурних чинників, для того щоб вони могли здійснювати самостійний вибір і користуватися багатством своїх можливостей... Наративна психотерапія зумовлює змінення ідентичності клієнта» (Ніколз \& Шварц, 2012: 407).

Ми приєднуємося до думки О.І. Копитіна і Б. Корта, які відзначають, що «переваги візуально-наративного підходу полягають у можливості глибокого і всебічного пророблення психологічного матеріалу на основі активності самого клієнта» (Копитін \& Корт, 2011: 50). Такий підхід дозволяє клієнту самому знайти і розкрити як значення візуальних образів, так і логічні зв'язки між образами. На думку D. Denborough, складно переоцінити переваги візуальнонаративного підходу при роботі 3 тими, хто відрізняється від більшості людей своїми звичками, цінностями, поглядами i/або способом життя - 3 різноманітними маргінальними групами або меншинами, наприклад, 3 людьми, які мають порушені стратегії харчової поведінки, нетрадиційну сексуальну орієнтацію та інші різноманітні форми порушень у поведінці, які достатньо часто спостерігаються при травматичному стресі (Denborough, 2006). На сьогодні різноманітні наративні техніки ефективно застосовуються провідними фахівцями української психологічної науки та практики (Калмиков, 2017; Титаренко, 2010; Чабан, 2012; Чаусова, 2011; Шебанова, 2017 та ін.) у роботі з людьми, які пережили психічну травму - гостру реакцію на стрес або посттравматичний стресовий розлад (у таборах біженців, у «гарячих точках», у ситуації окупації, міграції та ін.). Ми приєднуємося до тих авторів (Жорняк, 2005; Засєкіна та ін., 2018; Чепелєва, 2010; Berntsen et al., 2011; Nicnols \& Schwartz, 2012 та ін.), які особливу цінність цього підходу бачать не тільки у формі додаткового засобу психотерапевтичної роботи, але і як ефективного засобу психологічної самодопомоги.

На нашу думку, застосування візуально-наративного підходу (як поєднання візуальних стимулів та «письменництва» тексту 3 подальшим аналізом їхніх зв'язків 3 реальною життєвою історією) при роботі 3 людьми 3 розладами травматичного спектрує високоефективним та має значний ресурсний потенціал завдяки вирішенню цілого комплексу психокорекційних завдань, серед яких можна виокремити наступні: поліпшення суб'єктивного самопочуття 
Application of the Instrumentarium of a Visual-Narrative Approach...

і зміцнення психічного здоров'я; самодослідження учасників групи (клієнтів у індивідуальній терапії) для виявлення психологічних проблем («проблемних моментів життя»); розвиток навичок та внутрішніх механізмів опанування складними переживаннями, усвідомлення та вираження складних переживань; переосмислення минулого та орієнтація на позитивне майбутнє, набуття сенсу життя на основі розвитку самосвідомості, зростання самоприйняття та самоповаги як основи стабілізації емоційного стану та поведінкових змін; встановлення та розвиток взаємозв'язків 3 іншими людьми; вивчення способів міжособистісної взаємодії для створення основи ефективного i гармонійного спілкування 3 іншими; сприяння процесу особистісного розвитку, реалізації творчого потенціалу, досягненню оптимального рівня життєдіяльності.

Звернення до писемного мовлення (у процесі письменництва) дозволяє досягти більш високої концентрації почуттів i більш високого рівня опанування (контролю) над переживаннями у момент творчості або в момент озвучування (оповідання) свого творчого вербального продукту. Окрім того, для деяких людей письмове вираження думок та емоцій $є$ м'якшою, безпечною та комфортною формою вираження своїх уявлень і фантазій, ніж усне мовлення, оскільки дозволяє їм створити певну міжособистісну дистанцію і тим самим захистити свої особистісні межі (у разі недостатньої довіри до групи або психотерапевта).

Процес наративної психотерапії передбачає етап проходження екстерналізації проблеми (дистанціювання «проблеми» від людини). На думку М. Уайта, якщо людина описує себе за допомогою предикатів «занадто», «недостатньо» тощо (наприклад, «я занадто товста» або «я недостатньо струнка»), то вона тим самим постулює, що проблема «у ній самій» (Уайт, 1990, 2007). Таке формулювання, крім дискомфорту, який вже існує як хронічне відчуття незадоволеності собою, додає ще почуття сорому та провини. Щоб уникнути цього відчуття наративний підхід пропонує прийом «екстерналізації», який дозволяє дисоціюватися від «проблеми». При цьому остання може уявлятися як якась «Сутність», яка має свої плани, наміри на життя людини, стратегії, тактики, прийоми, які значущо відрізняються від намірів суб'єкта та заважають йому рухатися в оптимальному для нього напрямі. Таким чином, екстерналізація проблеми - це психотерапевтичний прийом, який 
спонукає учасників групи (клієнта у процесі індивідуальної роботи) об'єктивувати (персоналізувати) проблему шляхом створення вербального або образного продукту під час творчого процесу. Завдяки цьому проблема піддається трансформації, змінюється iii сприйняття і проблема стає тим, на що можна вплинути і що можна змінити (на відміну від позиції відчаю і безпорадності, коли певна проблема здається глобальною, невирішеною, незмінною i стабільною). Іншими словами, екстерналізація проблеми пом'якшує гостроту іiі переживання та забезпечує великі можливості для ii осмислення. Більш того, екстерналізація дозволяє включити проблему в більш широкий особистісний контекст, подивитися на неї з різних позицій та відшукати нові сенси. Це створює умови для переосмислення і переозначування проблеми, а надалі дозволяє людині виявити та відчути у собі нові можливості - ресурси, на основі яких стає можливим пошук альтернатив і зміна поведінки. Проблема сприймається як «об'єкт» на який можна впливати. Це дозволяє людині взяти на себе більшу відповідальність за характер зв'язків 3 «Проблемою», знизити почуття провини, підвищити якість власного життя та само ефективності (Гольденберг \& Гольденберг, 2012; Вайт \& Епстон, 1990, 2007). Зауважимо, що в цьому разі, коли проблема «виноситься за» і вже не належить людині, то вона «вміщується» у соціально-історичний контекст. Значну увагу масштабним культурним дискурсам, які підтримуються суспільством (зокрема, ідеям, які пов'язані з сучасною владою) приділяє в своїх працях М. Фуко. Автор звертає увагу, що сучасна влада на відміну від традиційної не зосереджена в руках однієї людини (сюзерена, царя, короля) та не обмежується тим, щоб забороняти, обмежувати, виносити моральне судження й карати. Вона невидима, іiї підтримують не конкретні особи, які мають владу, а всі члени певної культури. Сучасна влада спирається на винесення нормативного судження: в кожній культурі та субкультурі $є$ свої норми і стандарти того, що значить «відбутися як особистість», «жити правильно», «бути успішним», «гарно виглядати». Люди постійно порівнюють себе та інших з цими еталонами і приходять до висновку про власну «особистісну неспроможність», «зіпсовану ідентичність», «про невдалу долю», про необхідність приводити себе у відповідність до нормам (Фуко, 1980). 
Крім етапу екстерналізації, процес наративної психотерапії передбачає етап конструювання. Під даним терміном Ж. Дерріда розуміє критичний аналіз ідей, які були некритично засвоєні, тобто свого роду «розпакування» або «контекстуалізацію» (Дерріда, 1973). Використовуючи деконструювання, фахівець допомагає клієнту усвідомити, що уявлення або переконання, які домінують в його свідомості, $\epsilon$ «ілюзією», і що насправді реальність $є$ набагато різноманітнішою й ширшою. Основний сенс деконструкції як психотерапевтичного прийому, полягає в тому, щоб створити «якийсь простір» між людиною та ідеями, зробити ці ідеї видимими, щоб людина могла на них подивитися і оцінити їх вплив на себе. Пошук інших, нових варіантів дозволяє звільнити людину від «ілюзорних істин», розширює іï горизонти, надає їй відчуття свободи, сили та впевненості у досягненні нових можливостей. Реалізація такого творчого пошуку найбільш імовірна при написанні прози, віршів, пісень. На думку низки фахівців (Чабан, Хаустова, Олейнік, Е. Жабенко, Н. Жабенко, 2012), процес творчості нормалізує роботу мозку, стабілізує емоційні процеси та підвищує самоконтроль. Це дозволяє використовувати творчий процес під час психотерапевтичної корекції стресових станів, фобій, тривоги тощо (Чабан та ін., 2012: 45).

У власній психоконсультаційній та психотерапевтичній роботі ми часто застосовуємо різноманітні техніки, які $є$ інструментом екстерналізації вербальної продукції: есе, особисті історії, казки, вірші (зокрема, сінквейн та акровірш) і безліч різноманітних вправ на основі метафоричних асоціативних карт, які теж, звичайно, супроводжуються розгорнутим коментарем клієнта (Шебанова, 2014, 2016, 2017).

Нижче наведений фрагмент психодіагностичної та психотерапевтичної роботи 3 клієнтом на основі комбінації модифікованого тесту інверсії емоційного відображення та «метафоричних асоціативних карт» (техніки створення візуального ряду) (Шебанова, 2016).

Інформація про клієнтку (К.): Дівчинка, К., 15 років, 9-й клас. Антропометричні дані: ріст 164 см, вага - 55 кг, IMT - 20,5. Дівчинка навчається в ліцеї інтернатного типу 3 історико-філологічного напрямку та займається у гуртку «Юнкор» (спеціалізація «Журналістика»). 
Застосування інструментарію візуально-наративного підходу...

Запит батьків. Мати дівчинки звернулася із приводу того, що К. знепритомніла перед складанням колоквіуму. Було проведено медичне обстеження (терапевтом та невропатологом). За результатами обстеження не було виявлено жодної патології. Невропатолог рекомендував консультацію психолога.

Перша зустріч була присвячена встановленню контакту, збору анамнезу та психотерапевтичній бесіді. Були виявлені домінуючі особистісні риси (преморбідні особливості) К.: підвищена тривожність, наполегливість у досягненні мети, перфекціонізм (прагне вчитися тільки на «відмінно»), підвищена сенситивність до соціальних успіхів (засмучується, плаче, коли отримує оцінку «дев'ять»).

Під час консультації було з'ясовано, що К. пов'язує «ситуацію знепритомніння» 3 труднощами опанування власним емоційним станом під час складання будь-яких форм контролю. Саме тому частина зустрічі була присвячена навчанню К. деяким психогігієнічним способам зниження емоційної напруги (дихальноемоційним та м'язово-емоційним прийомам).

Друга зустріч була присвячення тестуванню за тестом інверсії емоційного відображення (в авторській модифікації) (Шебанова, 2016). У список слів-стимулів були включені слова «непритомність» та «окріп», оскільки під час цієї зустрічі дівчина повідомила про те, що вона знаходиться на стаціонарному лікуванні в опіковому відділенні (за три дні до зустрічі К. опеклась окропом у зонах спини, сідниць та щиколоток ніг). Результати тесту дозволили констатувати емоційне напруження (тривожність) психогенного характеру. Зафіксовано 19 слів-стимулів, на які не було надано асоціацій (зауважимо, що дівчинка займається у гуртку за напрямком «журналістика» та добре володіє «словом»). Зокрема, були відсутні асоціації на шість слів «тематичного характеру» (повнота, худоба, шоколад, корова, товстун, їжа) та на одинадцять слів емоціогенного характеру (хвороба, непритомність, ворожнеча, окріп, відчай, комфорт, обман, страх, втрата, травма). Крім того, відсутність реакції була зафіксована на нейтральні слова-стимули: голос, повітря, палеиь.

На третьому етапі тесту, відповідно до завдання, К. виокремила наступні три слова: корова, товстун, розпач, на основі яких склала два речення, які також виявилися діагностичними: 
Application of the Instrumentarium of a Visual-Narrative Approach...

«Якщчо бути товстою, як корова, можна вмерти від відчаю»; «Товстун, який схожий на корову, відчуває відчай». На запитання: «Як ця тематика пов'язана із твоїм реальним життям?», відповіла: «.. я ... як той товстун... задихаюся від відчаю». - Т.: «Що тебе рятує від відчаю?». К.: - «Любов та турбота мами».

Аналіз мовної продукції тесту дозволив висунути психотерапевтичну гіпотезу щодо наявності у клієнтки проблемної харчової поведінки (що було перевірено на третій консультації).

На третій зустрічі, під час психотерапевтичної бесіди було встановлено, що для К. дійсно актуальний «страх повноти» (дисморфоманічні та дисморфофобічні ідеї). - К: «Я боюся стати такою, як мій дідусь, у якого було 120 кг., нещодавно він помер від ожиріння. Рік тому я разом 3 дідусем «сіла» на дієту. Дідусеві так рекомендували лікарі, а я - «за компанію», оскільки теж бажала знизити свою вагу, щоб подобатися собі».

У ході уточнюючих запитань було з'ясовано, що 3 метою зниження ваги К. «організувала» собі жорстку обмежувальну дієту та виконує комплекс фізичних вправ тривалістю 30-40 хвилин до повного фізичного знесилення (ці дії виконуються нею вже упродовж трьох місяців). Скрупульозно стежить за вагою (зважується щодня).

Інформація, що була отримана під час психотерапевтичної зустрічі, дала підставу припустити, що причиною непритомності К. перед колоквіумом стала сукупність факторів - голодування та емоційного напруження. В подальшому у ході консультації К. відповідала на запитання авторської анкети щодо особливостей харчової поведінки. Наприклад, на запитання (3): «Коли ти дивишся на себе (своє відображення у дзеркалі), що тобі подобається в собі, а що ні?». К. відповіла: «мені все не подобається». - Т.: «Спробуй сказати більш конкретно. Що найбільше не подобається?»; - К.: «Обличчя» та «фігура». Далі наведемо фрагмент психотерапевтичної бесіди:

- Т.: Уяви собі, що ти малюєш фігуру людини. Які частини тіла, окрім обличчя та фігури, ти ще б намалювала? - К: Руки, ноги... - Т.: А ще? - К.: Тулуб... - Т.: А що намалювала б на тулубі? - К.: Груди, живіт, сідниці. - (терапевт письмово фіксує названі частини й пред'являє список К.) - Т.: Відзнач у складеному тобою списку ті частини тіла, які тобі не подобаються найбільше. Що б ти поставила на перше місце.., на друге..., третє? - К.: Живіт (1), 
сідниці (2), ноги (3). - Т.: Які частини тіла будуть на останніх місцях (на 8, 7, 6 місцях)? - К.: Руки (8 місце), груди (7-е), тулуб (6-е місце). Чи можу я зробити висновок, що руки, груди й тулуб, які зайняли останні місця у списку того, що тобі не подобається..., це ті частини тіла, які тобі більш-менш подобаються, і ти готова їх прийняти як такі, які подобаються? - К.: Так, мабуть, так... - Т.: Чи $є$ у твоєму оточенні значимі для тебе люди, які говорять тобі, що ти гарна, або приємна, або симпатична? - К.: Так, це мої батьки, дідусь із бабусею, ...але я їм не вірю, тому що для кожної мами (і інших родичів) своя дитина найкрасивіша та найгарніша. Ще $є$ хлопцідрузі й подружки, але їм я теж не вірю, тому що вважаю, що вони мені просто лестять. - Т.: Для чого їм це треба? Для чого твоїм друзям треба тобі лестити? - К.: У кожного є своя причина «вішати мені локшину на вуха»: хтось це робить із жалості, хтось - щоб я їм давала списувати уроки, хтось, щоб я їм вірила й любила... - Т.: А ти кому-небудь говориш компліменти? - К.: Так, звичайно. - Т.: Ти робиш це щиро? Твої компліменти відповідають тому, що ти думаєш? - К.: Так... Я не вмію «кривити душею»... і в мене немає причин комусь лестити... Я краще промовчу, ніж скажу неправду. - Т.: А що дає тобі підстави думати, що твоє оточення, твої друзі поступають інакше, не так, як ти? Що змушує тебе думати, що інші люди «влаштовані» по-іншому? - К.: Не знаю... - Т.: Це, дійсно, дуже складне питання. Пропоную витягнути «наосліп» карту, яка тобі в цьому допоможе (пропонується набір асоціативних карт «Спектрокарти» авторів: У. Халкола, А.І. Копитін). Опиши цю карту. Які відчуття вона в тебе викликає? Спираючись на це зображення спробуй відповісти на запитання: «Що змушує тебе думати, що інші люди «влаштовані» по-іншому?».

На основі асоціативної карти (див. рис. 1) К. надала відповідь: - Я думаю, що це мої власні сумніви у самій собі... це я сама... занадто невпевнена у собі - Т.: Що означають ці три фігури на карті? - К.: ...це моя «непевність», «нерішучість» та «мої страхи». - Т.: Про що твій страх? - К.: Я дуже боюся погладшати та стати такою ж товстою, як дідусь... Боюся, що буду відразливою та некрасивою, нікому не потрібною... Ніхто не зможе мене полюбити. - Т.: Я хочу звернути твою увагу, на той факт, що, 3 одного боку, ти прагнеш бути потрібною і прагнеш, щзоб тебе любили, а 3 іншого, коли оточуючі тебе близькі, друзі (юнаки й дівчата), 
Application of the Instrumentarium of a Visual-Narrative Approach...

прямим текстом говорять тобі про твою привабливість, ти кажеш: «...НЕ ВIPЮ!». У такому випадку, давай спробуємо разом пошукати шляхи вирішення такого протиріччя. Цьому ми присвятимо наступні зустрічі.

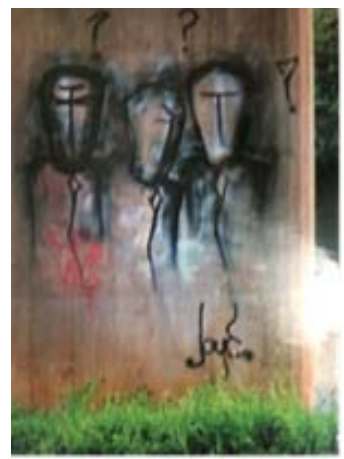

Рис. 1. Асоиіативна карта, яка ініціювала відповідь К. на запитання: Що змушує тебе думати, щзо інші люди «влаштовані» по-іншому?

Далі обговорювалося питання правильного, раціонального харчування. Терапевт звернула увагу на телевізійну програму «Зважені та щасливі», у якій обов’язковою умовою харчування «тих, що худнуть»є приймання їжі 5 раз у день.

- T: А зараз я пропоную тобі виконати ще одне дуже просте та легке завдання - (терапевт дає конструктор 3 кубиківцеглинок) - я прошу тебе побудувати чотирьохповерховий будинок. К. починає будувати..., зупиняється. - К.: А тут не вистачає... Я можу побудувати тільки двоповерховий будинок. - Т.: Так... тепер i я бачу, що на чотирьох поверховий будинок тут не вистачає матеріалу...тут тільки половина матеріалу від потрібної кількості. А скажи, будь ласка,... якби у нас із тобою була не ігрова ситуація, а реальна, життєва.... Я начальник будівництва, ти - прораб. I, якби я вимагала б від тебе завершення будівництва будинку, а забезпечила б тільки половиною матеріалу..., що б ти мені на це сказала? - К.: Що це безглуздо. - Т.: Дуже добре, i як прораб, ти професіонал високого рівня. А зараз давай також 3 позиції професіоналів обговоримо твій щоденний раціон 3 погляду доставки в нього енергетичного матеріалу, живильних речовин, цеглинок для будівництва храму твоєї душі...Тільки тепер ролі змінюються: ти - начальник будівництва. Твій організм - це твій 
прораб, який змушений тобі підкорятися... Що може сказати тобі твій організм, твій прораб, з врахуванням того, що ти не тільки половини будівельного матеріалу йому не даєш, а взагалі тримаєш його на «голодному пайку». - К.: ... так, він, напевно, погано буде думати про начальника. - Т.: Дай прорабу голос, і нехай він скаже начальнику все, що думає з цього приводу. - К.: Навіть не знаю, що сказати... - Т.: тоді допоможи собі та витягни наосліп ще одну карту (пропонується колода асоціативних карт); К. витягує наступну карту (див. рис. 2).

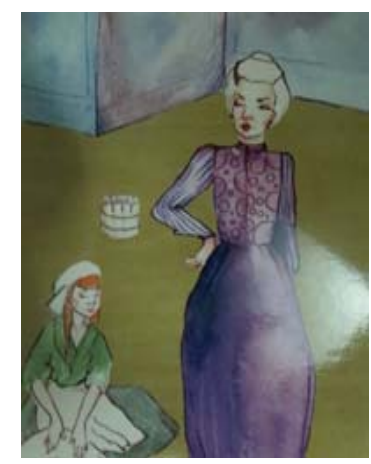

Рис. 2. Асоціативна карта, яку витягла К. наосліп

- Т.: Опиши цю карту. Які персонажі зображені на цій карті? Що відбувається між ними? - К.: - Це сценка 3 казки «Попелюшка». Попелюшка трудиться, миє підлогу, а мачуха говорить їй противним голосом: «погано миєш... от дивись плями залишилися...І чого тільки я тебе дармоїдку в домі тримаю? Задарма тільки годую...». - Т.: Які почуття виникають у тебе до цих персонажів? - К.: Попелюшку мені шкода. А мачуха - жорстока... - Т.: А якщо пов'язати цю карту 3 нашою ігровою ситуацією «начальника та прораба», то про що ця карта тобі підказує? - К.: Прораб - це нещасна Попелюшка, а начальник - це мачуха. - Т.: А якщо, «Попелюшка-Прораб» та «Мачуха-Начальниця» - це обидві твої частини, то як зробити Попелюшку щасливою? - К.: не знаю... може... перетворити мачуху в маму? - Т.: Я теж не знаю, але твоє рішення перетворити мачуху в маму мені здається досить благополучним варіантом вирішення даної ситуації. Які конкретні дії ти можеш зробити для перетворення «мачухи»у «маму», яка проявляє турботу та любов? Спробуй розпочати ці перетворення до 
Application of the Instrumentarium of a Visual-Narrative Approach...

нашої наступної зустрічі. У завершення нашої зустрічі я пропоную тобі домашнє завдання...».

Даний приклад відображує динаміку внутрішніх змін, яка відбувалася завдяки роботі з наративом клієнта. Застосування МАК дозволило зробити процес цих змін і трансформацій видимими, наочними та усвідомленими.

\section{Висновки}

Проведене дослідження та досвід нашої науково-практичної роботи дозволяє відзначити високу ефективністьрізних технік візуально-наративного підходу під час надання психологічної допомоги щодо вирішеннярізних психологічних проблем. Техніки, які презентовані нами у наших попередніх публікаціях дозволяють 3 одного боку, діагностувати актуальну проблематику клієнта, його емоційний стан, копінг-стратегії поведінки, а 3 іншого допомагають актуалізувати та висловлювати значущі для себе почуття і ідеї, які здатні передати персональне ставлення до себе i світу i надають той наративний матеріал, спираючись на який клієнт починає усвідомлювати та змінювати власне ставлення до проблемної ситуації, знаходити ресурси щодо іiї подолання. Перспективою подальших досліджень вважаємо розробку та застосування методик та технік у візуально-наративному підході.

\section{Література}

Выготский, Л.С. Мышление и речь. Москва : Лабиринт, 1999. 352 с.

Жорняк, Е.С. Нарративная психотерапия. Журнал практической психологии и психоанализа. 2005. № 4. URL : http://www.psyjournal.ru/psyjournal/articles/ detail.php?ID=2678

Засєкіна, Л., Хворост, Х., Засекіна, Д. Травматичний наративу координатах психолінгвістичного дослідження. Psycholinguistics. Психолінгвістика. Психолингвистика. 2018. Вип. 23(1). С. 47-59. doi:10.5281/zenodo.1211097

Калмиков, Г. Професійно-психологічний дискурс як інструмент впливу на адресата. Psycholinguistics. Психолінгвістика. Психолингвистика. 2017. Вип. 22(1). С. 104-123. doi:10.5281/zenodo.1087770

Копытин, А.И., Корт, Б. Техники телесно-ориентированной арт-терапии. Москва : Психотерапия, 2011. 128 с.

Сарбин, Т.Р. Нарратив как базовая метафора психологии. Постнеклассическая психология. Социальный конструкционизм и нарративный подход. 2004. № 1. C. 6-28.

Титаренко, Т.М. Постмодерна особистість в динаміці самоконструювання. Актуальні проблеми психологіі: Психологічна герменевтика. Н.В. Чепелєва (ред.). Київ. 2010. Т. 2. Вип. 6. С. 5-14. 
Застосування інструментарію візуально-наративного підходу...

Чабан, О., Хаустова, Е., Жабенко, Е., Олейник, А., Жабенко, Н. Тревога: история сверхбеспокойных людей. Киев : Pfizer, 2012. 130 с.

Чаусова, Ю.А. Наративний підхід у дослідженні особливостей сімейних стосунків. Актуальні проблеми психології: Психологічна герменевтика. 2011. Том II. Вип. 7. С. 227-234.

Чепелева, Н.В. Методологические основы исследования личности в контексте постнеклассической психологии. Актуальні проблеми психології: Психологічна герменевтика. Н.В. Чепелєва (ред). Київ : ДП «Інформаційноаналітічне агенство». 2010. Том 2. Вип. 6. С. 15-24.

Шебанова, В.И. Тренинг нормализации пищевого поведения: Программа психологического сопровождения на пути к свободе от переедания. Практическое руководство. Херсон : ПП Вишемирский В.С., 2014. 394 с.

Шебанова, B.I. Феноменологія харчової поведінки у континуумі «нормапатологія». Херсон : ПП Вишемирський В.С., 2016. 612 с.

Шебанова, В.I. Застосування техніки «складання віршів» щодо нормалізації девіантної поведінки. Напрями соціально-психологічної роботи iз засудженими до покарань, не пов'язаних з позбавленням волі: Матеріали науково-практичного семінару для співробітників Південного міжрегіонального управління з питань виконання кримінальних покарань та апробації Міністерства юстиції України (м. Херсон, 30 травня 2017 року). Херсон : ХДУ, 2017. С. 41-43.

Berntsen, D., Rubin, D.C., \& Siegler, I.C. (2011). Two versions of life: emotionally negative and positive life events have different roles in the organization of life story and identity. Emotion, 11(15), 1190-201. doi: 10.1037/a0024940

Bruner, J.S. (2003). Making Stories: Law, Literature, Life. New York : Farrar, Strauss and Giroux.

Busquets, J.J. (2018). Fer-hoAnaphorain Catalan: Semanticand Discourse Properties. Journal of Psycholinguistic Research, 47(2), 307-324. https://doi.org/10.1007/ s10936-017-9538-3

Deleuze, G. (1993). Critique etclinique. Pariz : Editions de Minuit.

Denborough, D. (2006). Trauma: Narrative responses to traumatic experiences. Adelaide : Dulwich Cetre Publicationsa.

Derrida, J. (1973). Speech and phenomena, and other essays on Husserl's theory of signs. Evanston, IL : Northwestern University Press.

Foucault, M. (1980). The Politics of Healthinthe Eighteenth Century. In C. Gordon (Ed.), Power. Knowledge: Selected Interviews and Other Writings 1972-1977 (pp. 166-182). New York : Pantheon.

Friedman, J.G. (1996). Combs Narrative therapy: the social construction of preferred realities. New York : W. Norton \& Company.

Geertz, C. (1973). The Interpretation of Cultures. New York : Basic Books.

Goffman, E. (1986). Stigma: Notes on the Management of Spoiled Identity. New York : Prentice-Hall.

Goldenberg, H., \& Goldenberg, I. (2012). Family therapy: an overview. $8^{\mathrm{ed}}$. New York : Cengage Learning.

Myerhoff, B. (1992). Remembered Lives: The Work of Ritual, Storytelling and Growing Older. In Virginia Tufte, Marc Kaminsky (Eds.). Michigan : University of Michigan Press.

Nicnols, M.P., \& Schwartz, R.C. (2012). Family therapy concepts and methods. $10^{\text {ed }}$. Boston : Pearson. 
Pesco, D., \& Kay-Raining Bird, E. (2016). Perspectiveson bilingual children's narratives elicited with the Multilingual Assessment Instrument for Narratives. Applied Psycholinguistics, 37(1), 1-9. doi:10.1017/S0142716415000387

Ray, P.H., \& Anderson, S.R. (2001). The Cultural Creatives: How 50 million people are changing the world. New York : Harmony Books.

Turner, V.W., \& Bruner, E.M. (1986). The Anthropology of Experience. Urbana : University of Illinois Press.

White, M. (2007). Maps of Narrative Practice. New York : W.W. Norton \& Company. White, M., \& Epston, D. (1990). Narrative Means to Therapeutic Ends. New York : W.W. Norton.

\section{References}

Vygotskij, L.S. (1999). Myshlenie $i$ rech [Thinking and speaking] (5 th $^{\text {ed.). }}$ Moscow : Labirint [in Russian].

Zhornjak, E.S. (2005). Narrativnaja psihoterapija [Narrative psychotherapy]. Zhurnal prakticheskoj psihologii $i$ psihoanaliza - Journal of Practical Psychology and Psychoanalysis, 4. URL : http://www.psyjournal.ru/psyjournal/articles/detail. php?ID=2678 [in Russian].

Zasekina, L., Hvorost, H., \& Zasekina, D. (2018). Travmatychnyi naratyv u koordynatakh psykholinhvistychnoho doslidzhennia [Traumatic narrative in the psycholinguistic studydimension]. Psiholingvistika - Psycholinguistics, 23(1), 4759. doi:10.5281/zenodo.1211097 [inUkrainian].

Kalmykov, G. (2017). Profesiyno-psihologichniy diskurs yak instrument vplivu na adresata [Professional and psychological discourse as an instrument of influence on the addressee]. Psiholingvistika - Psycholinguistics, 22(1), 104-123. doi: $10.5281 /$ zenodo.1087770 [in Ukrainian].

Kopytin, A.I., \& Kort, B. (2011). Tehniki telesno-orientirovannoj art-terapii [Techniques of body-orientedart therapy]. Moscow : Psihoterapija [in Russian].

Sarbin, T.R. (2004). Narrativ kak bazovaja metafora psihologii [Narrative as the basic metaphor of psychology]. Postneklassicheskaja psihologija. Socialnyj konstrukcionizm $i$ narrativnyj podhod - Postnonclassical psychology. Social constructivism and narrative approach, 1, 6-28 [in Russian].

Titarenko, T.M. (2010). Postmoderna osobistist v dinamici samokonstruju vannja [Postmodern personality in the dynamics of self-design]. Aktualni problemi psihologii: Psihologichna germenevtika - Actual problems of psychology: Psychological hermeneutics, 2(6), 5-14 [in Ukrainian].

Chaban, O., Haustova, E., Zhabenko, E., Olejnik, A., \& Zhabenko, N. (2012). Trevoga: istorija sverhbespokojnyh ljudej [Anxiety: the story of over-worried people]. Kyiv : Pfizer [in Ukrainian].

Chausova, Ju.A. (2011). Narativnij pidhid u doslidzhenni osoblivostej simejnih stosunkiv [Narrative approach in the study of the characteristics of family relation ships]. Aktualni problemi psihologii: Psihologichna germenevtika Actual problems of psychology: Psychological hermeneutics, 2 (7), 227-234 [in Ukrainian].

Chepeleva, N.V. (2010). Metodologicheskie osnovy issledovanija lichnosti v kontekste postneklassicheskoj psihologii [Methodological bases of the study of personality in the context of post-nonclassical psychology]. Aktualni problemi psihologii: Psihologichna germenevtika - Actual problems of psychology: Psychological hermeneutics], 2(6), 15-24 [in Ukrainian]. 
Застосування інструментарію візуально-наративного підходу...

Shebanova, V.I. (2014). Trening normalizacii pishhevogo povedenija: Programma psihologicheskogo soprovozhdenija na puti $k$ svobode ot pereedanija. Prakticheskoe rukovodstvo [Training for normalization of eating behavior: A program of psychological support on the way to freedom from overe ating. A Practical Guide]. Herson : PP Vishemirskij V.S. [in Ukrainian].

Shebanova, V.I. (2016). Fenomenolohiya kharchovoyi povedinky u kontynuumi «norma - patolohiya» [Phenomenology of food behavior in the continuum «norm - pathology»]. Kherson : PP Vyshemirsky V.S. [in Ukrainian].

Shebanova, V.I. (2017). Zastosuvannia tekhniky «skladannia virshiv» shchodo normalizatsii deviantnoi povedinky [Applying the technique of «compilation of poems» to normalize deviant behavior]. Napriamy sotsialno-psykholohichnoi roboty iz zasudzhenymy do pokaran, nepoviazanykh z pozbavlenniam voli Directions social and psychological work with prisoner stop unishment other than imprisonment. Proceedings of the Scientific and Practical Workshop for the Employees of the Southern Interregional Department for the Execution of Criminal Sentences and Probation of the Ministry of Justice of Ukraine. Kherson : vydavnytstvo KhDU, (pp. 41-43) [in Ukrainian].

Berntsen, D., Rubin, D.C., \& Siegler, I.C. (2011). Two versions of life: emotionally negative and positive life events have different roles in the organization of life story and identity. Emotion, 11 (15), 1190-201. doi: 10.1037/a0024940

Bruner, J.S. (2003). Making Stories: Law, Literature, Life. New York : Farrar, Strauss and Giroux.

Busquets, J.J. (2018). Fer-ho Anaphorain Catalan: Semantic and Discourse Properties. Journal of Psycholinguistic Research, 47(2), 307-324. https://doi.org/10.1007/ s10936-017-9538-3

Deleuze, G. (1993). Critique etclinique. Pariz : Editions de Minuit.

Denborough, D. (2006). Trauma: Narrative responses to traumatic experiences. Adelaide : Dulwich Cetre Publicationsa.

Derrida, J. (1973). Speech and phenomena, and other essays on Husserl's theory of signs. Evanston, IL : Northwestern University Press.

Foucault, M. (1980). The Politics of Healthin the Eighteenth Century. In C. Gordon (ed.), Power. Knowledge: Selected Interviews and Other Writings 1972-1977 (pp. 166-182). New York : Pantheon.

Friedman, J.G. (1996). Combs Narrative therapy: the social construction of preferred realities. New York: W. Norton \& Company.

Geertz, C. (1973). The Interpretation of Cultures. New York : Basic Books.

Goffman, E. (1986). Stigma: Notes on the Management of Spoiled Identity. New York : Prentice-Hall.

Goldenberg, H., \& Goldenberg, I. (2012). Family therapy: an overview. $8^{\mathrm{ed}}$. New York : Cengage Learning.

Myerhoff, B. (1992). Remembered Lives: The Work of Ritual, Storytelling and Growing Older. In Virginia Tufte \& Marc Kaminsky (Eds.). Michigan : University of Michigan Press.

Nicnols, M.P., \& Schwartz, R.C. (2012). Family therapy concepts and methods. $10^{\text {ed }}$. Boston : Pearson.

Pesco, D., \& Kay-Raining Bird, E. (2016). Perspectiveson bilingual children's narratives elicited with the Multilingual Assessment Instrument for Narratives. Applied Psycholinguistics, 37(1), 1-9. doi:10.1017/S0142716415000387

Ray, P.H., \& Anderson, S.R. (2001). The Cultural Creatives: How 50 million people are changing the world. New York : Harmony Books. 
Application of the Instrumentarium of a Visual-Narrative Approach...

Turner, V.W., \& Bruner, E.M. (1986). The Anthropology of Experience. Urbana : University of Illinois Press.

White, M. (2007). Maps of Narrative Practice. New York : W.W. Norton \& Company. White, M., \& Epston, D. (1990). Narrative Means to Therapeutic Ends. New York : W.W. Norton.

\section{АНОТАЦІЯ}

У статті акцентовано увагу на застосуванні інструментарію візуальнонаративного підходу при наданні психологічної допомоги особистості. Показано, що наративний підхід наразі широко застосовуються фахівцями щодо розв'язання різноманітного спектру психологічних проблем особистості, нормалізації психологічного стану особистості у кризових і травматичних ситуаціях.

Реалізація наративного підходу здійснюється завдяки створенню усних та письмових текстів під час надання психологічної допомоги. Поєднання вербального творчого продукту з метафоричними асоціативними картами, фотографіями, листівками, малюнками, мандалами тощо дозволяє виокремлювати візуально-наративний підхід. «Тексти» як відгук на візуальні стимули (асочіативні карти, фотографії, малюнок, мандалу та ін.) можуть бути будь-якого характеру (біографрічного або франтазійного) та будь-якого стилю (проза, римовані та неримовані вірші, казки, особисті історії, есе та ін.). В одному варіанті візуальний ряд може бути первинними, а тексти вторинними. При цьому «текстом» може бути просто розгорнутий коментар учасника групи (клієнта) або творчий авторський текст, який складає клієнт. В іншому варіанті, навпаки, первинними можуть бути тексти, а до них потім добираються візуальні стимули, які теж у подальшому описуються та аналізуються в їхньому зв'язку з реальною життєвою історією клієнта. Презентовано основні положення та принципи наративного підходу. Наведені етапи наративної психотерапії: екстерналізації проблеми (дистанціювання "проблеми» від людини); конструювання (реконструювання) - критичний аналіз ідей, які були некритично засвоєні, тобто свого роду "розпакування» або «контекстуалізацію». Показано, що наративний підхід розглядається як: - засіб розвитку особистісних особливостей, досягнення ідентичності; - форма усвідомлення особистого досвіду; - засіб організації особистісного майбутнього і самоконституювання; метод аналізу міжпоколінної історії або корекційний сімейний психотерапевтичний метод. Зроблений акцент на особливій цінності даного підходу як ефективного засобу психологічної самодопомоги.

Ключові слова: візуально-наративний підхід, психологічна допомога, самодопомога, кризові ситуації, травматичні ситуації, пошук ресурсів, само- і життєконструювання. 
Застосування інструментарію візуально-наративного підходу...

Шебанова Виталия, Тавровецкая Наталья. Применение инструментария визуально-нарративного подхода при психологической помощи личности

\section{АННОТАЦИЯ}

В статье акцентировано внимание на применении инструментария визуально-нарративного подхода при оказании психологической помощи личности. Показано, что нарративный подход широко применяется специалистами для решения широкого спектра психологических проблем личности, нормализации психологического состояния личности в кризисных и травматических ситуациях.

Реализация нарративного подхода осуществляется благодаря созданию устных и письменных текстов во время оказания психологической помощи. Сочетание вербального творческого продукта с метафорическими ассоциативными картами, фотографиями, открытками, рисунками, мандалами и т.п. позволяет выделить визуально-нарративный подход. "Тексты», как отклик на визуальные стимулы (ассоциативные карты, фотографии, рисунок, мандалу и др.) могут быть любого характера (биографического или франтазийного) и любого стиля (проза, рифмованные и нерифмованные стихи, сказки, личные истории, эссе и др.). В одном варианте визуальный ряд может быть первичными, а тексты вторичными. При этом «текстом» может быть просто развернутый комментарий участника группы (клиента) или творческий авторский текст, который составляет клиент. В другом варианте, наоборот, первичными могут быть тексты, а к ним потом добираются визуальные стимулы, которые тоже в дальнейшем описываются и анализируются в их связи с реальной жизненной историей клиента. Представлены основные положения и принципы нарративного подхода. Показаны этапы нарративной психотерапии: экстернализации проблемы (дистанцирование «проблемы» от человека) конструирования (реконструкции) - критический анализ идей, которые были некритически усвоенные, то есть своего рода "распаковки» или «контекстуализация». Обосновывается, что нарративный подход рассматривается как: средство развития личностных особенностей, достижения идентичности; форма осознания личного опыта; средство организации личностного будущего и самоконструирования; метод анализа межпоколенной истории или коррекционный семейный психотерапевтический метод. Сделан акцент на особой ценности данного подхода как эфрективного средства психологической самопомощи.

Ключевые слова: визуально-нарративный подход, психологическая помощь, самопомощь, кризисные ситуации, травматические ситуации, поиск ресурсов, само- и жизнеконструирование. 